\title{
Changes in peripheral blood lymphocyte subsets during arthritis development in arthralgia patients
}

Joyce Lübbers ${ }^{1,6^{*}}$ (D, Marian H. van Beers-Tas², Saskia Vosslamber ${ }^{1}$, Samina A. Turk², Sander de Ridder ${ }^{1}$, Elise Mantel', John G. Wesseling ', Martine Reijm', Ingrid M. van Hoogstraten', Johannes W. Bijlsma', Dirkjan van Schaardenburg ${ }^{2,4}$, Hetty J. Bontkes ${ }^{1,5}$ and Cornelis L. Verweij ${ }^{1 \wedge}$

\begin{abstract}
Background: Multiple lymphocyte subsets like T and B cells have been connected to joint infiltration and inflammation in rheumatoid arthritis (RA). Identification of leucocyte subsets that are dysregulated in arthritis development could provide insight into the aetiology of RA. This study aimed to investigate the composition of the peripheral blood components, i.e. CD14 $4^{+}$monocytes, $\mathrm{CD} 4^{+}$and $\mathrm{CD} 8^{+}$T lymphocytes $\left(\mathrm{CD} 3^{+}\right), \mathrm{CD} \mathrm{O}^{+}, \mathrm{C}-\mathrm{X}-\mathrm{C}$ chemokine receptor $3(\mathrm{CXCR} 3)^{+}$and $\mathrm{CD} 27^{+}$B lymphocytes $\left(\mathrm{CD} 19^{+}\right), \mathrm{CD}_{16} 6^{+} \mathrm{CD} 56^{+} \mathrm{CD} 3^{-}$natural killer (NK) cells and activated $\mathrm{CD}_{56}{ }^{+} \mathrm{CD}^{+} \mathrm{T}$ cells, for association with arthritis development in patients with arthralgia.

Methods: Peripheral blood was collected from 89 patients with early RA (disease duration $<6$ months), 37 healthy controls (HC) and 113 patients with arthralgia (22 developed arthritis within $\leq 1$ year, 18 developed arthritis after $>1$ year and 73 did not develop arthritis). Absolute numbers of monocytes and lymphocyte subsets in whole heparinized blood were determined with flow cytometry using quantification beads in combination with fluorescent labelled antibodies for T cells, B cells, monocytes, NK cells and activated T cells.

Results: In patients with early RA, significant decreases in numbers of (activated) T cells, $C D 80^{+}$and memory B cells and a trend towards smaller numbers of $\mathrm{CD}^{+} \mathrm{T}$ cells was observed compared to HC. Similar differences were seen in patients with arthralgia who developed or did not develop arthritis (non-converters), with significantly decreased CD8 ${ }^{+} \mathrm{T}$ cells and memory B cells. Patients with arthralgia who developed arthritis were split into groups that developed arthritis within 1 year (early converters) or after 1 year (late converters). Late converters had a significantly decreased number of $\mathrm{CD}^{+} \mathrm{T}$ cells compared to non-converters; early converters had a decreased number of memory B cells. Longitudinal analysis of converters showed a significant relative increase in $\mathrm{CD}^{\circ} \mathrm{O}^{+} \mathrm{B}$ cells towards the conversion time point compared to 24 months prior to conversion.
\end{abstract}

Conclusions: This study revealed that patients with arthralgia who develop arthritis demonstrate a change in cellular immune parameters apparent in the periphery, starting with a decrease in cytotoxic T cells 24 months prior to arthritis development, followed by a decrease in the number of memory B cells 12 months prior to disease onset.

(Continued on next page)

\footnotetext{
*Correspondence: j.lubbers@vumc.nl

Deceased

'Department of Pathology, VU University Medical Center, Amsterdam, The Netherlands

${ }^{6}$ Department of Pathology, VU University Medical Center, Inflammatory Disease profiling Unit, CCA2.21, P.O. box 7075, Amsterdam 1007MB, The Netherlands

Full list of author information is available at the end of the article
} 
(Continued from previous page)

Keywords: Rheumatoid arthritis, Arthralgia, Cell subsets, Flow cytometry

Abbreviations: ACPA, anti-citrullinated peptide antibodies; APC, allophycocyanin; CXCR3, C-X-C chemokine receptor 3; DMARDs, disease-modifying anti-rheumatic drugs; FITC, fluorescein isothiocyanate; HC, healthy controls; IFN, interferon; MFI, mean fluorescent intensity; NK, natural killer; PE, phycoerythrin; PerCP, peridinin chlorophyll protein; RA, rheumatoid arthritis; RF, rheumatoid factor

\section{Background}

Rheumatoid arthritis (RA) is an autoimmune disease affecting the joints. Inflammation of the joints leads to destruction of bone and cartilage in the joint [1]. Although the aetiology of the disease is still unknown it is likely that inadvertent immune activation is the basis for the development of RA. Understanding the immune mechanism and components that lead to chronic joint inflammation is of utmost importance to allow timely identification and treatment in order to prevent arthritis development and concomitant joint destruction.

Among these immune components are autoantibodies against citrullinated peptides (APCA) and rheumatoid factor (RF), which are seen years before the clinical manifestation of RA $[2,3]$. More recently we have identified the presence of the type I interferon (IFN) signature in peripheral blood cells in $52 \%$ of patients with arthralgia who developed arthritis within 2 years [4]. Moreover, we provided evidence that a decreased $\mathrm{B}$ cell count, corresponding to lower memory B cell numbers, in the periphery, is associated with arthritis development [5].

In this study we analysed the peripheral blood components, i.e. $\mathrm{CD}_{14}{ }^{+}$monocytes, $\mathrm{CD} 4^{+}, \mathrm{CD}^{+}$and $\mathrm{CD}^{+} 6^{+} \mathrm{T}$ lymphocytes $\left(\mathrm{CD}^{+}\right), \mathrm{CD}^{+} 0^{+}, \mathrm{C}-\mathrm{X}-\mathrm{C}$ chemokine receptor

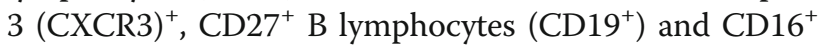
$\mathrm{CD} 6^{+} \mathrm{CD}^{-} \mathrm{NK}$ cells, for their association with arthritis development. We therefore, studied individuals who were seropositive and had joint complaints without swelling of the joints, i.e. patients defined as having arthralgia. These patients were followed until the development of arthritis, defined as having at least one swollen joint. Furthermore, we investigated the variability of the frequency of the different cell subsets over the course of arthritis development in these patients.

\section{Methods}

\section{Study population}

The Amsterdam Reade cohort used for this study consisted of 113 patients with arthralgia of whom 22 developed arthritis within 1 year (converters $\leq 12$ months) and 18 developed arthritis after 1 year (converters $>12$ months). Inclusion criteria for the patients with arthralgia were positivity for ACPA and/or RF [6], joint complaints without clinical arthritis determined by two independent rheumatologists and a minimum follow-up period of 24 months. Exclusion criteria for the patients with arthralgia were the (previous) use of diseasemodifying anti-rheumatic drugs (DMARDs), a history of arthritis and evidence of erosions on radiographs. Arthritis was defined as having one or more swollen joints as assessed by two independent rheumatologists. Furthermore, 37 healthy controls ( $\mathrm{HC}$ ) and 89 patients with early RA were included at Reade. Inclusion criteria for the patients with early RA were disease duration $<6$ months and no previous use of DMARDS or biological agents. See Table 1 for demographic and clinical characteristics of all study groups.

\section{Flow cytometry analysis}

Absolute numbers and percentage of monocytes and lymphocyte subsets were determined with flow cytometry (FACS Calibur) on whole heparinized blood. Quantification beads (Trucount, BD) in combination with CD45 fluorescein isothiocyanate (FITC), CD14 phycoerythrin (PE), CD3 peridinin chlorophyll protein (PerCP) and CD19 allophycocyanin (APC) were used to measure absolute numbers of lymphocytes, monocytes, B cells and T cells according to the manufacturer's instructions. Absolute numbers of cell subsets were calculated using the percentage of cells within a main cell type that was measured with quantification beads. For the subsets CD45 and CD3 or CD19 were always taken in multiple tubes combined with the following markers: CD8 PE, CD4 APC, CD16/56 PE, CXCR3 APC, CD80 PE and CD27 FITC (all products from BD Biosciences, San Jose, CA, USA). Flow cytometry data were analysed using FACSDIVA software version 6.1.3. Forward, sideward scatter and CD45 $5^{\text {bright }}$ were used to select lymphocytes. $\mathrm{CD}_{16}{ }^{+} \mathrm{CD} 56^{+} \mathrm{CD} 3^{-}$cells were defined as natural killer (NK) cells and $\mathrm{CD} 16 / \mathrm{CD}^{+} 6^{+} \mathrm{CD}^{+}$cells are expected to be predominantly $\mathrm{CD} 56^{+} \mathrm{CD} 16^{-}$. As $\mathrm{CD} 56^{+} \mathrm{CD} 3^{+} \mathrm{T}$ cells, also described as NK T-like cells, have been described as activated effector cells $[7,8]$ we define them here as activated $\mathrm{T}$ cells. Gating strategy is depicted in Additional file 1: Figure S1.

\section{Statistical analyses}

GraphPad Prism 5.0 was used for statistical analysis. The Mann-Whitney $U$ test or Kruskal-Wallis test followed by Dunn's multiple comparison test were used to compare 
Table 1 Demographic characteristics of healthy controls, patients with arthralgia and patients with early RA

\begin{tabular}{|c|c|c|c|c|c|c|}
\hline \multirow{3}{*}{ Individuals (n) } & \multirow{3}{*}{$\begin{array}{l}\text { Healthy } \\
\text { controls }(\mathrm{HC}) \\
\\
37\end{array}$} & \multicolumn{4}{|c|}{ Patients with arthralgia } & \multirow{2}{*}{$\begin{array}{l}\text { Patients with } \\
\text { early RA }\end{array}$} \\
\hline & & \multirow{2}{*}{$\begin{array}{l}\text { All patients } \\
\text { with arthralgia } \\
113\end{array}$} & \multirow{2}{*}{$\begin{array}{l}\text { Arthritis development } \\
<1 \text { year (early converters) } \\
22\end{array}$} & \multirow{2}{*}{$\begin{array}{l}\text { Arthritis development } \\
>1 \text { year (late converters) } \\
18\end{array}$} & \multirow{2}{*}{$\begin{array}{l}\text { Did not } \\
\text { develop arthritis } \\
\text { (non-converters) } \\
73\end{array}$} & \\
\hline & & & & & & 89 \\
\hline $\begin{array}{l}\text { Median age at inclusion in } \\
\text { years (IQR) }\end{array}$ & $30(27-41)$ & $50(41-57)$ & $55(32-65)$ & $45(39-57)$ & $51(41-58)$ & $53(42-60)$ \\
\hline Female $(n)(\%)$ & $16(64)$ & $86(76)$ & $17(77)$ & $14(78)$ & $55(75)$ & $59(66)$ \\
\hline ACPA positive (n) (\%) & N.D. & $69(61)$ & $18(82)$ & $16(89)$ & $35(48)$ & $53(60)^{a}$ \\
\hline RF positive (n) (\%) & N.D. & $50(44)$ & $12(55)$ & $5(28)$ & $33(45)$ & $49(55)^{\mathrm{a}}$ \\
\hline ACPA and RF positive (n) (\%) & N.D. & $29(26)$ & $11(50)$ & $6(33)$ & $12(16)$ & $43(48)^{a}$ \\
\hline $\begin{array}{l}\text { Median follow-up time in } \\
\text { months (IQR) }\end{array}$ & N.A. & $26.9(19.1-42.4)$ & $8.1(1.3-12.3)$ & $22.3(13.9-41.6)$ & $36(25.7-47.9)$ & N.A. \\
\hline $\begin{array}{l}\text { Median time to arthritis } \\
\text { development in months (IQR) }\end{array}$ & N.A. & $12.48(7.4-22.1)$ & $8.1(1.3-12.3)$ & $22.3(13.9-41.6)$ & N.A. & N.A. \\
\hline
\end{tabular}

${ }^{a}$ Available for 87 out of 89 patients. RA rheumatoid arthritis, $H C$ healthy controls, N.A. not applicable, N.D. not determined, ACPA anti-citrullinated peptide antibodies, $R F$ rheumatoid factor, IQR interquartile range

the different parameters between patient groups. $\log ^{2}$ values were used for the ratios, showing the timeframe from conversion time point and 12 or 24 months prior to conversion. The one sample $t$ test or Wilcoxon signed rank test was used to test if the median was significantly different from 0 , which would indicate an increase or decrease from the conversion time point. $P$ values $<0.05$ were considered to be significant.

\section{Results}

In order to gain insight into the immune differences between $\mathrm{HC}$ and patients with early RA, the number of circulating monocytes, lymphocytes, NK cells, activated $\mathrm{T}$ cells, B cells, $\mathrm{T}$ cells and $\mathrm{B}$ and $\mathrm{T}$ cell subsets were assessed by flow cytometry. This revealed that patients with early RA had a significantly lower overall number of circulating $\mathrm{CD}^{+}{ }^{+} \mathrm{T}$ cells, $\mathrm{CD}^{+} \mathrm{CD} 56^{+} \mathrm{CD} 16^{+}$activated $\mathrm{T}$ cells, conventional memory $\left(\mathrm{CD} 27^{+}\right) \mathrm{B}$ cells and activated $\left(\mathrm{CD} 80^{+}\right) \mathrm{B}$ cells compared to $\mathrm{HC}$ (Fig. 1). There was a similar trend in the number of $\mathrm{CD}^{+}$cytotoxic $\mathrm{T}$ cells. The number of monocytes (data not shown), overall lymphocytes (data not shown), $\mathrm{CD} 4^{+} \mathrm{T}$ helper cells, $\mathrm{B}$ cells and migration marker $(\mathrm{CXCR} 3)^{+} \mathrm{B}$ cells did not differ between $\mathrm{HC}$ and patients with early RA. This indicates that memory B cells may have left the circulation in patients with early RA.

Next we compared the same lymphocyte subsets at the inclusion time point in patients with arthralgia who developed arthritis within 5 years (converters) with patients with arthralgia who did not develop arthritis (non-converters). This revealed that converters had a significant lower number of $\mathrm{CD} 8^{+}$cytotoxic $\mathrm{T}$ cells and $\mathrm{CD}^{2} 7^{+}$memory B cells compared to non-converters (Fig. 2). There was no significant decrease in migration marker $(\mathrm{CXCR} 3)^{+} \mathrm{B}$ cells between non-converters and patients with early arthritis $(p=0.18)$. A significant decrease was observed in $\mathrm{CD} 27^{+}$memory B cells in patients with early RA compared to non-converters and HC ( $p=0.008$ and $p=0.036$, respectively). Differences between $\mathrm{HC}$, non-converters, converters and patients with early arthritis are depicted in Additional file 2: Figure S2. This indicates that some of the difference in the immunological status of patients with early RA have already occurred in converters by the first visit to the rheumatologist.

In the Amsterdam Reade cohort, the patients with arthralgia were followed by a rheumatologist for research purposes, for a maximum of 5 years, to determine whether arthritis developed. Therefore, in this cohort, arthritis could occur between the time point of inclusion and at a maximum follow up of 5 years. To investigate whether there was a difference in the composition of circulating mononuclear cells at the inclusion time point between patients with arthralgia who developed arthritis within a year and between 1 and 5 years, the converters were divided into early and late converter groups. This revealed that the late converters had a significantly lower number of $\mathrm{CD}^{+}$cytotoxic $\mathrm{T}$ cells compared to nonconverters (Fig. 3). No differences between late converters and non-converters were observed for B cells, memory B cells or activation and migration markers. In the early converters there was a significant decrease in the number of memory B cells (Fig. 3). The same trend was visible for the overall number of $B$ cells and the activation and migration marker-positive $B$ cells.

The data as described suggest that cytotoxic $\mathrm{T}$ cells and memory $\mathrm{B}$ cells leave the periphery before the clinical diagnosis of arthritis. To gain more insight into the 


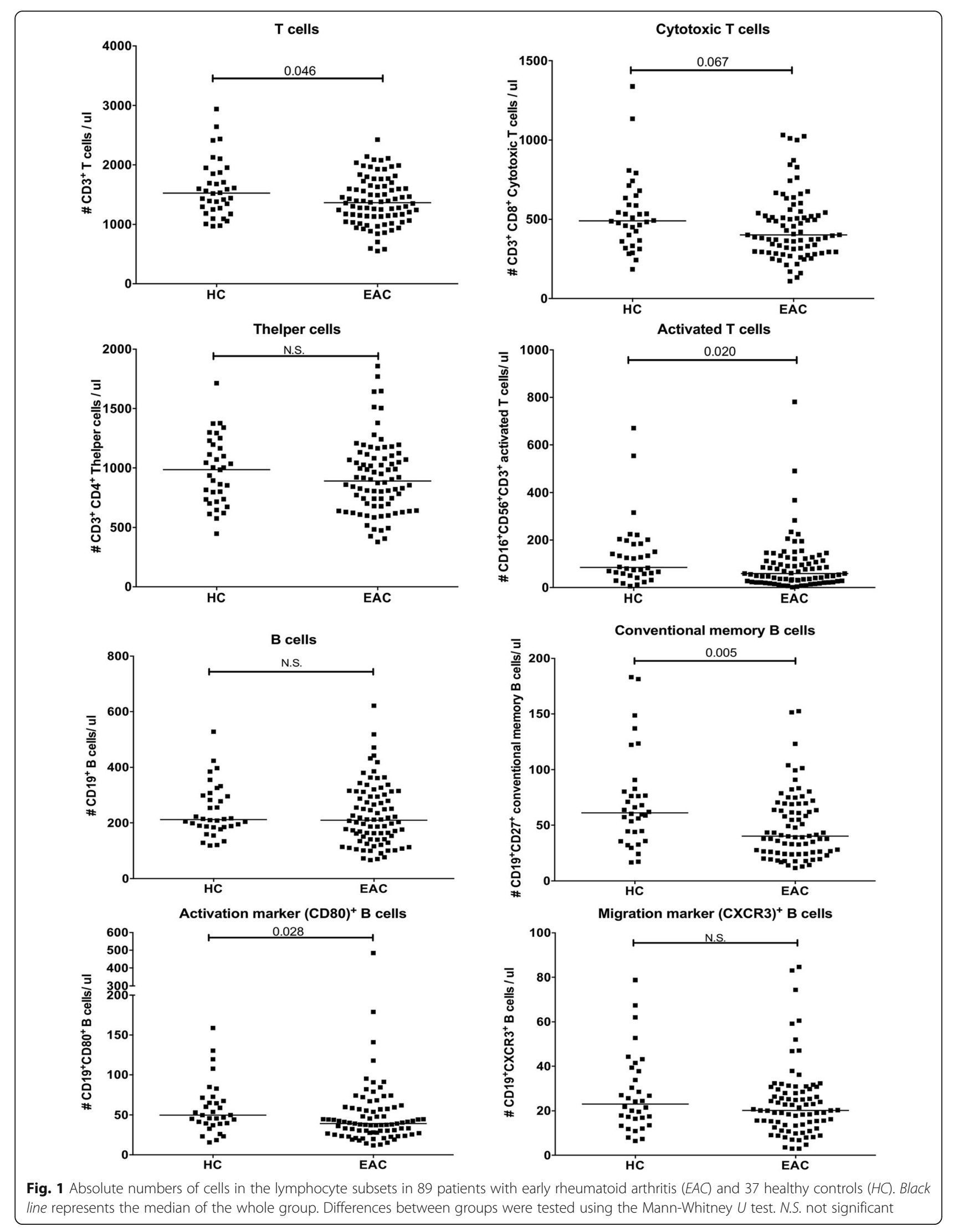



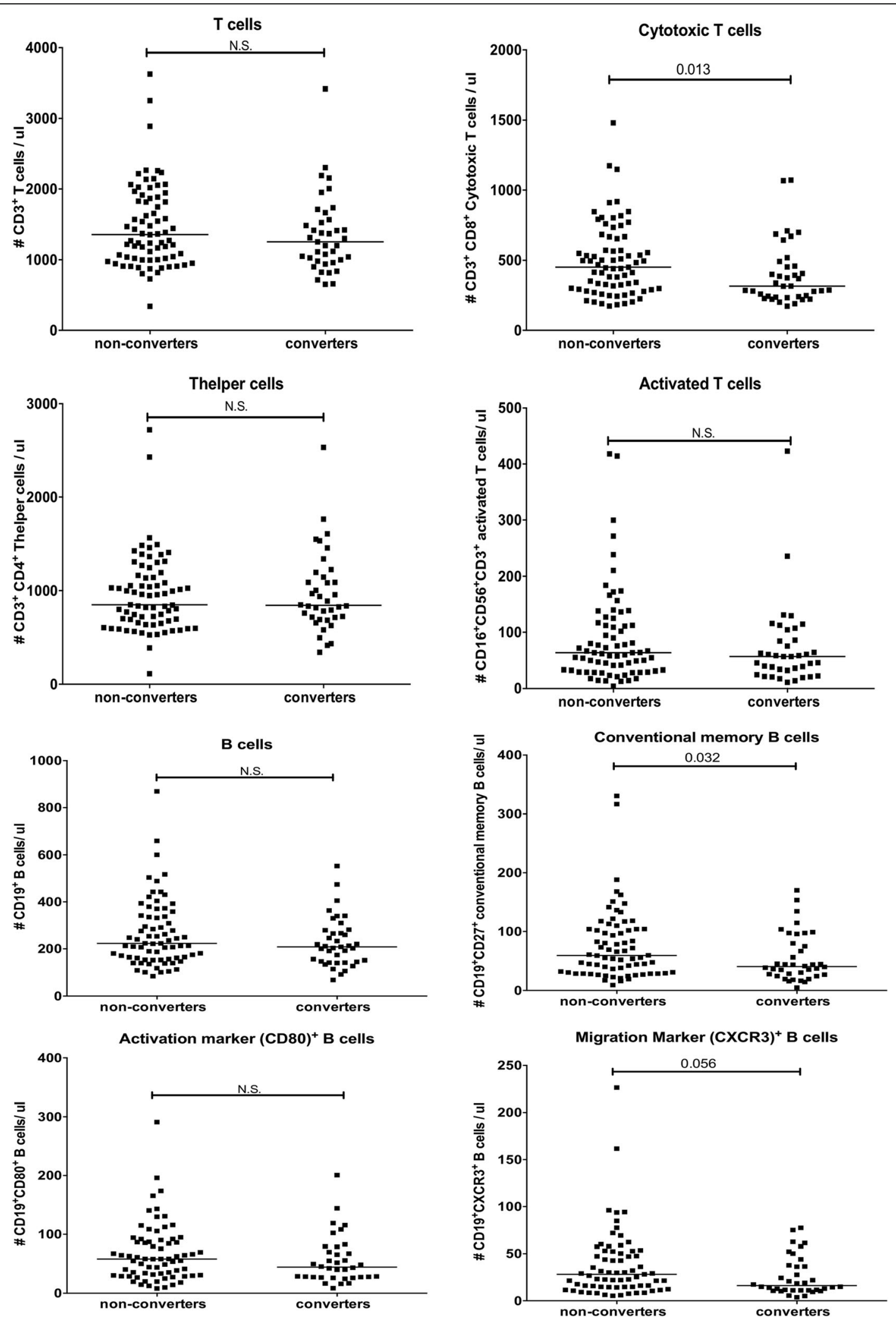

Fig. 2 Absolute numbers of cells per lymphocyte subset in 40 patients with arthralgia who developed arthritis within 5 years (converters) and 73 patients with arthralgia who did not develop arthritis (non-converters). Black line represents median of the whole group. Differences between groups were tested using the Mann-Whitney $U$ test. N.S. not significant 

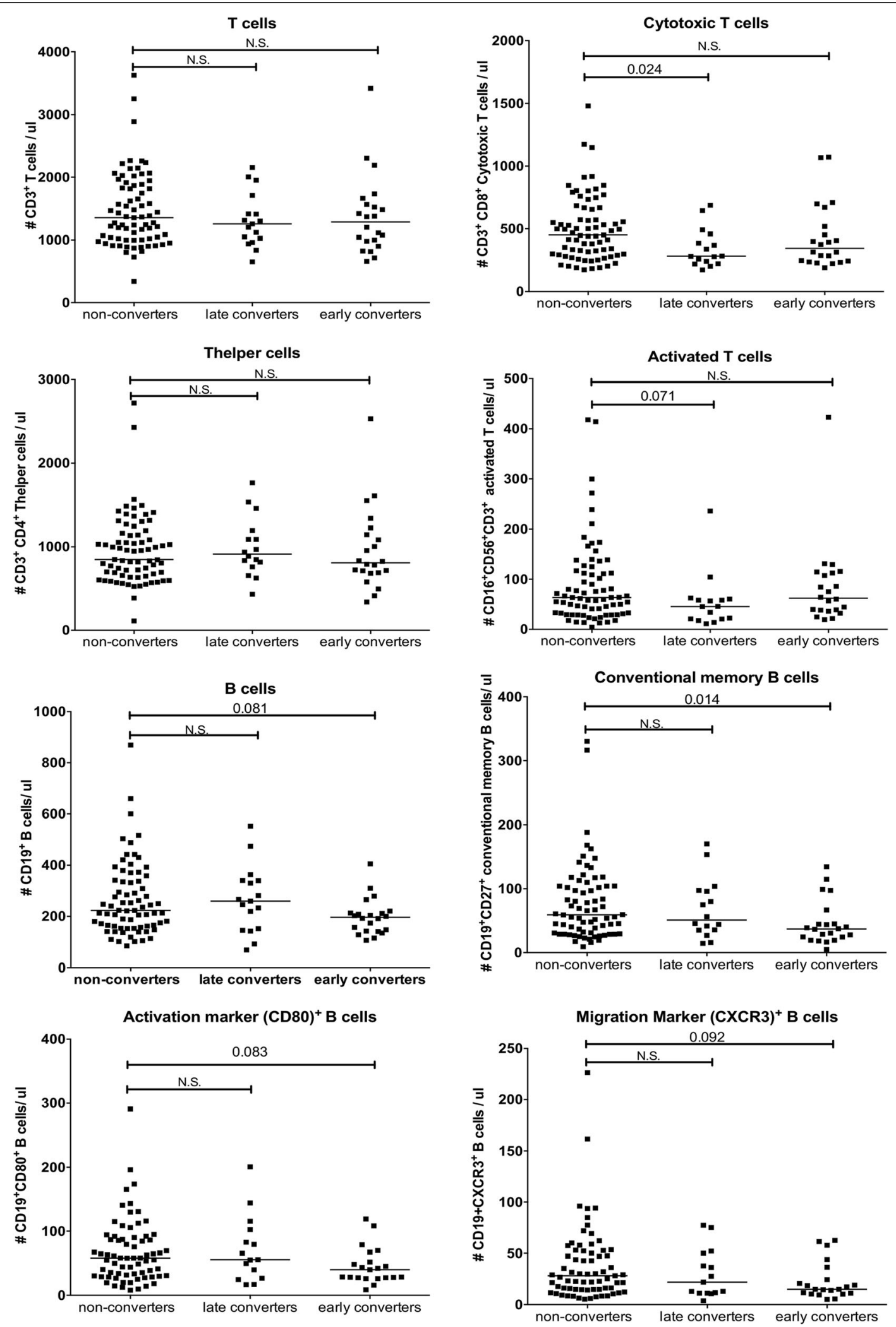

Fig. 3 (See legend on next page.) 
(See figure on previous page.)

Fig. 3 Absolute numbers of cells per lymphocyte subset in 73 patients with arthralgia who did not develop arthritis (non-converters), 22 who developed arthritis within a year (early converters) and 18 who developed arthritis after 1 to 5 years (late converters). Black line represents the median of the whole group. Differences between groups were tested using the Kruskal-Wallis test followed by Dunn's multiple comparison test. N.S. not significant

time frames of action for these cell types, we investigated a small group of 17 converters using flow cytometry measurements at the time point of conversion and 12 and/or 24 months prior to conversion. Additional file 3: Figure S3 depicts the changes over time in both converting and 68 non-converting patients with arthralgia. To more clearly depict the changes in converters at 12 or 24 months prior to conversion, $\log ^{2}$ ratios were calculated to show the relative increase or decrease compared to the conversion time point. This revealed that there was a broad distribution within the cell types, where one patient showed a relative increase towards conversion and the other revealed a relative decrease towards the conversion time point (Fig. 4). The most outstanding cell types were the activation-marker-positive B cells, which showed a significant relative increase towards the conversion time point compared to 24 months prior to conversion. This may indicate that in the very early stages, possibly years before the development of arthritis, cytotoxic $\mathrm{T}$ cells and conventional memory $\mathrm{B}$ cells migrate towards the lymph nodes or the joints.

\section{Discussion}

Changes in immune parameters and B cells in particular, have been extensively studied in the peripheral blood of patients with RA in relation to therapy response, pathology of RA and clinical parameters. In patients with early RA, a decrease in total memory B cells and an increase in serum markers for the activation of $\mathrm{B}$ cells such as beta 2 microglobulin have been described $[9,10]$. We have recently described lower numbers of memory B cells as a potential biomarker to predict arthritis development in patients with arthralgia [5]. In the present study, we demonstrate that changes in peripheral blood mononuclear subsets, especially a smaller number of $\mathrm{CD}^{+} \mathrm{T}$ cells were seen 24 months prior to developing arthritis, whereas 12 months prior to arthritis development, the number of memory B cells was lower compared to patients with arthralgia who did not develop arthritis.

Our data demonstrate that there is a clear difference between patients with early RA and $\mathrm{HC}$, with a decrease in $\mathrm{CD}^{+}$cytotoxic $\mathrm{T}$ cells, $\mathrm{CD}^{+}{ }^{+} \mathrm{CD} 56^{+} \mathrm{CD} 16^{+}$activated $\mathrm{T}$ cells, memory $\mathrm{B}$ cells and activated $\mathrm{B}$ cells in patients with early RA. This could be partly due to the age differences between the $\mathrm{HC}$ and the patients with early RA, as it patients with established RA have a prematurely aged immune system that is about 20 years older than the healthy controls [11]. However, our data suggest that these changes start early in the development of RA, as converters with arthralgia display similar changes. Late converters had smaller numbers of $\mathrm{CD}^{+}$cytotoxic $\mathrm{T}$ cells, whereas the early converters had a decrease in memory B cells. The smaller number of memory B cells found in the peripheral blood of early converters and patients with early RA is similar to what is described by McComish et al. for DMARD-naïve patients with early RA [12]. This reduced number could be due to migration of memory B cells to the synovium of the affected joints.

We observed trends towards decreased activated B cells and $\mathrm{CXCR}^{+} \mathrm{B}$ cells, which suggests increased migration of activated $\mathrm{B}$ cells to the joints. These populations and $\mathrm{CD}_{2} 7^{+}$memory $\mathrm{B}$ cells may be partly overlapping [13]. Increased migration of these subsets is in line with the study of Nanki et al. describing more memory B cells and CXCR3-positive B cells in the synovium compared to the peripheral blood in patients with early RA [14]. Alternatively, B cells may have migrated towards the lymph nodes or bone marrow. In patients with early RA significantly more B cells were observed in the draining lymph nodes of the inflamed joints than in similar lymph nodes among HC [15]. In patients with established RA the bone marrow adjacent to the affected joints reveals a cell-rich inflammatory environment instead of a fat-rich non-inflammatory environment as seen in HC [16]. Both the increase in cells in the lymph nodes of patients with arthralgia and a more inflammatory environmebn in the bone marrow adjacent to the affected joints in patients with RA point towards a systemic immune activation in patients with arthralgia in whome B cells may migrate towards the secondary lymphoid organs, bone marrow or joints approximately a year before clinical signs arise.

Reduced numbers of $\mathrm{CD}^{+}$cytotoxic $\mathrm{T}$ cells are associated with early arthritis, as there was a trend towards lower numbers in the patients with early arthritis and a significant reduction in (late) converters compared to non-converters. It has previously been described that in patients with established RA no significant differences were found in $\mathrm{T}$ cell subsets compared to $\mathrm{HC}$; , however there was a shift seen towards more CD8+ terminally differentiated effector memory $\mathrm{T}$ cells [17]. This might point towards early activation of cytotoxic $\mathrm{T}$ cells in arthralgia and in patients with early RA, which may later differentiate into the terminally differentiated effector memory $\mathrm{T}$ cells found in patients with established RA. There are indications that there is increased migration 


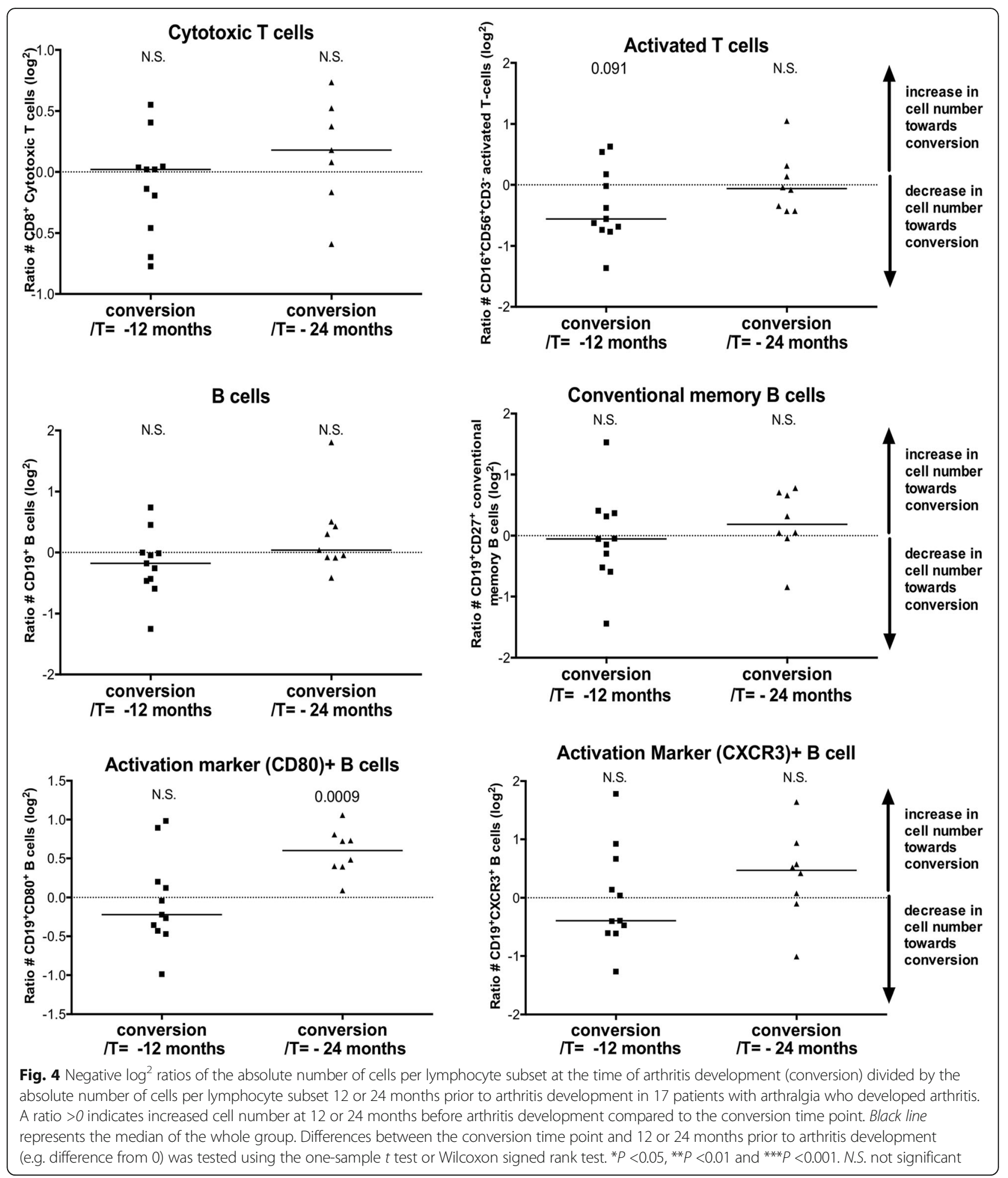

of $\mathrm{CD}^{+}$cytotoxic $\mathrm{T}$ cells to the lymph nodes and joints in patients with RA. In the lymph nodes of patients with early RA and patients with arthralgia who did not develop RA, there were no differences in the frequency of total $\mathrm{CD}^{+}$cytotoxic $\mathrm{T}$ cells. However, there was a significant increase in activated $\mathrm{CD}^{+} 9^{+} \mathrm{CD} 8^{+} \mathrm{T}$ cells in the lymph nodes of patients with early $\mathrm{R}$, and a tendency towards this in patients with arthralgia [15]. de Hair et al., described subtle infiltration of $\mathrm{CD}^{+}$cytotoxic $\mathrm{T}$ cells in the synovium of patients with arthralgia [18]. 
These data suggest that cytotoxic $\mathrm{T}$ cells in patients with arthralgia become more activated in the lymph nodes before migrating towards the affected joints, which might accelerate the inflammation in the joint by producing more pro-inflammatory cytokines [19]. No differences were observed in $\mathrm{CD}^{+} \mathrm{T}$ helper cells between $\mathrm{HC}$, non-converters, converters and patients with early RA. This is in concordance with a recent publication on $\mathrm{CD}^{+}{ }^{+} \mathrm{T}$ cells, reporting no differences in the absolute number of $\mathrm{CD}_{4}^{+} \mathrm{T}$ cells or in $\mathrm{CD} 4^{+}$ (terminally differentiated) effector memory cells between $\mathrm{HC}$ and seropositive patients with arthralgia. An increase in $\mathrm{CD}^{+}{ }^{+} \mathrm{CD} 161^{+} \mathrm{T}$ cells expressing a $\mathrm{TH} 17$ or $\mathrm{TH} 1 / \mathrm{TH} 17$ phenotype was observed in seropositive patients with arthralgia compared to $\mathrm{HC}$, suggesting a role for TH17 cells in RA development [20]. Our data suggest that increased migration of $\mathrm{B}$ cell subsets and $\mathrm{CD} 8^{+}$cytotoxic $\mathrm{T}$ cells is reflected by decreased numbers of these subsets in peripheral blood; however, larger studies are necessary to confirm this.

Recently seropositive patients with arthralgia were reported to have a decreased percentage of NK cells, especially CD56 ${ }^{\mathrm{dim}} \mathrm{NK}$ cells, compared to $\mathrm{HC}$ [21]; however, there were no differences in absolute numbers of NK cells within the $\mathrm{CD} 45^{+}$pool. In our comparison of converting and non-converting seropositive patients with arthralgia there was no decrease in the absolute numbers or percentage (data not shown) of overall NK cells; however, there was no sub-classification of NK cells on CD56 ${ }^{\text {dim }}$ or CD56 $^{\text {bright }}$. Furthermore, no differences in NK cells between $\mathrm{HC}$, non-converting and converting patients with arthralgia and patients with early RA were observed. This could be due to differences in patient population and inclusion criteria for the patients with arthralgia.

Longitudinal data for the patients with arthralgia among both non-converters and converters show that there was fluctuation in the percentage of all immune cells that we measured. This could be a reflection of the normal fluctuation that we also observed in $\mathrm{HC}$ or due to seasonal infections like the influenza virus; however, patients with symptoms of influenza were asked to return at a later time point for blood collection. What emerged from the longitudinal data, although from a small cohort, is the significant increase in the number of activated B cells within patients between 12 and 24 months before conversion. Our study provides indications of which immune cell subsets and changes therein are involved in the phase preceding development of clinical RA. Larger studies are needed to better understand the time points of these changes, as well as the transitions between the blood, bone marrow, lymph node and synovial compartments. These studies will enable more precise prediction for clinical use and the definition of time points and targets for specific interventions.

\section{Conclusions}

The main conclusion from this study is that patients with arthralgia who develop arthritis have changes in circulating lymphocyte subsets, starting with a decrease in $\mathrm{CD}^{+}$cytotoxic $\mathrm{T}$ cells 24 months prior to arthritis development, followed by a decrease in the number of activated memory B cells 12 months prior to disease onset.

\section{Additional files}

\begin{abstract}
Additional file 1: Figure S1. Gating strategy of the flow cytometry analysis. A Gating strategy with quantification beads. Gate 1 for living cells, which are depicted in the second dot plot. Gate 2 for lymphocytes, gate 3 for monocytes and gate 4 for the quantification beads. CD3 and CD19 positivity was determined in the lymphocyte gate and depicted in plot 5. B Gating strategy for the immunological subsets. Lymphocyte selection based on FSC and SSC properties (plot 1) followed by selection on CD45 properties (plot2). All the subsets were determined in the lymphocyte gate. (TIF 3403 kb)
\end{abstract}

Additional file 2: Figure S2. Dot plots of the absolute number of cells in the lymphocyte subsets in 37 healthy controls (HC), 40 patients with arthralgia who developed arthritis within 5 years (converters), 73 patients with arthralgia who did not develop arthritis (non-converters) and 89 patients with early RA (EAC). The black line represents median of the whole group. Differences between groups were tested with the Kruskal-Wallis test followed by Dunn's multiple comparison test. N.S. not significant. (TIF $791 \mathrm{~kb}$ )

Additional file 3: Figure S3. Line plot of the absolute number of cells per lymphocyte subset in 68 non-converting and 17 converting patients with arthralgia. The non-converting patients are depicted from the time point of inclusion. The converting patients are depicted from the time point of conversion and the time before conversion. (TIF $1784 \mathrm{~kb}$ )

\section{Acknowledgements \\ The authors thank J. Hollander, P. Bonnet and the other technicians of the Unit of Medical Immunology, Department of Pathology, VU University Medical Center, The Netherlands for their help with flow cytometry data collection. We would also like to thank S. Snel of the Department of Haematology, VU University Medical Center, The Netherlands for his help with the FACS DIVA software.}

\section{Funding}

This research was performed with support from the consortium in the framework of the Centre for Translational Molecular Medicine (CTMM)(Http:// www.ctmm.nl) and the Dutch Arthritis Foundation (grant 11-1-411 and LLP-20).

\section{Availability of supporting data}

Data are not publicly available.

\section{Authors' contributions}

All authors were involved in drafting the article or revising it critically for important intellectual content, and all authors approved the final version to be published. JL, MvB, SAT, EM, JGW and MR contributed to the acquisition of patient material and or data. JL, SV, IMvH, SdR, JWB, DvS, HJB and CLV made substantial contributions to data analysis and/or interpretation of the data.

\section{Authors' information}

Not applicable.

Competing interests

The authors declare that they have no competing interests.

Consent for publication

Not applicable. 


\section{Ethical approval and consent to participate}

All patients gave written informed consent and the study was approved by the regional ethics committee (Medical Ethics Committee

Slotervaartziekenhuis and Reade, Amsterdam, The Netherlands).

\section{Author details}

'Department of Pathology, VU University Medical Center, Amsterdam, The Netherlands. ${ }^{2}$ Amsterdam Rheumatology and Immunology Center, Jan van Breemen Research Institute | Reade, Amsterdam, The Netherlands.

${ }^{3}$ Amsterdam Rheumatology and Immunology Center, VU University Medical Center, Amsterdam, The Netherlands. ${ }^{4}$ Amsterdam Rheumatology and Immunology Center, Academic Medical Centre, Amsterdam, The Netherlands. ${ }^{5}$ Department of Oral Cell Biology, ACTA, Amsterdam, The Netherlands. ${ }^{6}$ Department of Pathology, VU University Medical Center, Inflammatory Disease profiling Unit, CCA2.21, P.O. box 7075, Amsterdam 1007MB, The Netherlands.

Received: 6 May 2016 Accepted: 25 August 2016

Published online: 14 September 2016

\section{References}

1. Drossaers-Bakker KW, De Buck M, Van Zeben D, Zwinderman AH, Breedveld FC, Hazes JMW. Long-term course and outcome of functional capacity in rheumatoid arthritis: the effect of disease activity and radiologic damage over time. Arthritis Rheum. 1999;42:1854-60.

2. Rantapää-Dahlqvist S, De Jong BA, Berglin E, Hallmans G, Wadell G, Stenlund $\mathrm{H}$, et al. Antibodies against cyclic citrullinated peptide and IgA rheumatoid factor predict the development of rheumatoid arthritis. Arthritis Rheum. 2003:48:2741-9.

3. Nielen MMJ, Van Schaardenburg D, Reesink HW, Van De Stadt RJ, Van Der Horst-Bruinsma IE, De Koning MHMT, et al. Specific autoantibodies precede the symptoms of rheumatoid arthritis: a study of serial measurements in blood donors. Arthritis Rheum. 2004:50:380-6.

4. Lübbers J, Brink M, van de Stadt LA, Vosslamber S, Wesseling JG, van Schaardenburg D, et al. The type I IFN signature as a biomarker of preclinical rheumatoid arthritis. Ann Rheum Dis. 2013;72:776-80. Available from: http://ard.bmj.com/content/72/5/776.long.

5. Lübbers J, Vosslamber S, Van De Stadt LA, van Beers-Tas MH, Wesseling JG, von Blomberg BME, et al. B cell signature contributes to the prediction of RA development in patients with arthralgia. Ann Rheum Dis. 2015;74:1786-9. Available from: http://ard.bmj.com/content/74/9/1786.long.

6. Bos WH, Dijkmans BA, Boers M, van de Stadt RJ, van Schaardenburg D. Effect of dexamethasone on autoantibody levels and arthritis development in patients with arthralgia: a randomised trial. Ann Rheum Dis. 2010;69:571-4.

7. Kelly-Rogers J, Madrigal-Estebas L, O'Connor T, Doherty DG. Activationinduced expression of CD56 by T cells is associated with a reprogramming of cytolytic activity and cytokine secretion profile in vitro. Hum Immunol. 2006;67:863-73.

8. Cookson S, Reen D. IL-15 drives neonatal T cells to acquire CD56 and become activated effector cells. Blood. 2003;102:2195-7.

9. Gottenberg J-E, Miceli-Richard C, Ducot B, Goupille P, Combe B, Mariette X. Markers of B-lymphocyte activation are elevated in patients with early rheumatoid arthritis and correlated with disease activity in the ESPOIR cohort. Arthritis Res Ther. 2009:11:R114.

10. Moura RA, Weinmann P, Pereira PA, Caetano-Lopes J, Canhão H, Sousa E, et al. Alterations on peripheral blood B-cell subpopulations in very early arthritis patients. Rheumatology. 2010;49:1082-92.

11. Weyand CM, Shao L, Goronzy JJ. Immune aging and rheumatoid arthritis. Rheum Dis Clin North Am. 2010;36:297-310.

12. Mccomish J, Mundy J, Sullivan T, Proudman SM, Hissaria P. Changes in peripheral blood B cell subsets at diagnosis and after treatment with disease-modifying anti-rheumatic drugs in patients with rheumatoid arthritis: correlation with clinical and laboratory parameters. Int J Rheum Dis. 2015;18:421-32.

13. Wei C, Jung J, Sanz I. Phenotypic Analysis of human memory B cells. Cytom A. 2011;79:894-6

14. Nanki T, Takada K, Komano Y, Morio T, Kanegane H, Nakajima A, et al. Chemokine receptor expression and functional effects of chemokines on $B$ cells: implication in the pathogenesis of rheumatoid arthritis. Arthritis Res Ther. 2009;11:R149.
15. van Baarsen LGM, de Hair MJH, Ramwadhdoebe TH, Zijlstra IJAJ, Maas M, Gerlag DM, et al. The cellular composition of lymph nodes in the earliest phase of inflammatory arthritis. Ann Rheum Dis. 2013;72:1420-4. Available from: https://www.ncbi.nlm.nih.gov/pmc/articles/PMC3711496.

16. Bugatti S, Vitolo B, Caporali R, Montecucco C, Manzo A. B cells in rheumatoid arthritis: from pathogenic players to disease biomarkers. Biomed Res Int. 2014; 2014:681678. Available from: https:/www.ncbi.nlm.nih.gov/pmc/articles/ PMC4022166/.

17. Fekete A, Soos L, Szekanecz Z, Szabo Z, Szodoray P, Barath S, et al. Disturbances in $B$ - and T-cell homeostasis in rheumatoid arthritis: suggested relationships with antigen-driven immune responses. J Autoimmun. 2007:29:154-63.

18. de Hair MJH, van de Sande MGH, Ramwadhdoebe TH, Hansson M, Landewé $\mathrm{R}$, van der Leij $\mathrm{C}$, et al. Features of the synovium of individuals at risk of developing rheumatoid arthritis: implications for understanding preclinical rheumatoid arthritis. Arthritis Rheumatol. 2014:66:513-22. Available from: https://www.ncbi.nlm.nih.gov/pmc/articles/PMC4034588/.

19. Feldmann M, Brennan FM, Maini RN. Role of cytokines in rheumatoid arthritis. Annu Rev Immunol. 1996;14:397-440.

20. Chalan P, Kroesen BJ, Van Der Geest KSM, Huitema MG, Abdulahad WH, Bijzet J, et al. Circulating CD4 + CD161+ T lymphocytes are increased in seropositive arthralgia patients but decreased in patients with newly diagnosed rheumatoid arthritis. PLoS One. 2013:8:1-11.

21. Chalan P, Bijzet J, Kroesen B-J, Boots AMH, Brouwer E. Altered natural kille cell subsets in seropositive arthralgia and early rheumatoid arthritis are associated with autoantibody status. J Rheumatol. [Internet]. 2016;43. Available from: http://www.jrheum.org/content/43/6/1008.long.

\section{Submit your next manuscript to BioMed Central and we will help you at every step:}

- We accept pre-submission inquiries

- Our selector tool helps you to find the most relevant journal

- We provide round the clock customer support

- Convenient online submission

- Thorough peer review

- Inclusion in PubMed and all major indexing services

- Maximum visibility for your research

Submit your manuscript at www.biomedcentral.com/submit
C) Biomed Central 